\title{
Genotypes of Hepatitis C Virus in Relapsed and Non-respondent Patients and their Response to Anti-Viral Therapy in District Mardan, Khyber Pakhtunkhawa, Pakistan
}

\author{
Noreen Akhtar ${ }^{1}$, Muhammad Bilal', Muhammad Rizwan ${ }^{1 *}$, Muhammad Asif \\ Khan $^{2}$, Aurangzeb Khan ${ }^{2}$
}

\begin{abstract}
Hepatitis $\mathbf{C}$ is a blood-borne infectious disease of liver, caused by a small enveloped, positive-single stranded RNA virus, called the hepatitis $\mathrm{C}$ virus (HCV). HCV belongs to the Flaviviridae family and has 6 genotypes and more than 100 subtypes. It is estimated that 185 million people are infected with $\mathrm{HCV}$ worldwide and $\mathbf{5 \%}$ of these are in Pakistan. The study was designed to evaluate different genotypes of HCV circulating in District Mardan and to know about the behavior of these genotypes to different anti-viral regimes. In this study 3,800 patients were exposed to interferon alfa-2a plus Ribavirin treatment for 6-months and subjected to real-time PCR to check the viral response. Among these 3,677 (97\%) patients showed no detectable HCV RNA while 123 (3\%) patients (non-responders) remained positive for HCV RNA. Genotypes of their analyzed showed that most of them belonged to the 3a genotype. Non-responders (123) and relapsed (5) patients were subjected to PEG-interferon and Ribavirin therapy for next 6 months, which resulted into elimination of HCV RNA from 110 patients. The genotypes of the persisting resistant samples to anti-viral treatment were $3 \mathrm{~b}, 2 \mathrm{a}, 1 \mathrm{a}$ and $1 \mathrm{~b}$. Furthermore, viral RNA from 6 patients remained un-typed while 4 patients showed mixed infections. HCV was found more resistant to antiviral therapy in females as compared to mals. The age group 36-45 in both females and males was found most affected by infection. In general 3a is the most prevalent genotype circulating in district Mardan and the best anti-viral therapy is PEG-interferon plus Ribavirin but it is common practice that due to the high cost patients receive interferon alfa-2a plus Ribavirin with consequent resistance in $3 \%$ patients given this treatment regime.
\end{abstract}

Keywords: HCV infection - anti-viral treatment - interferon - Ribavirin - resistance - PEG-interferon - Pakistan

Asian Pac J Cancer Prev, 16 (3), 1037-1040

\section{Introduction}

Hepatitis $\mathrm{C}$ is a blood-borne infectious disease of liver, caused by Hepatitis C virus (Frank et al., 2000). Hepatitis $\mathrm{C}$ infection causes acute and chronic hepatitis (Kanda et al., 2013). When a person first infected with hepatitis $C$ virus, it can develop an acute infection, which may be a very mild illness with few or no symptoms or may be a very serious condition, in which the patient might be hospitalized. Acute hepatitis $\mathrm{C}$ is a short-term illness which occurs within the first six months after the infection with hepatitis $\mathrm{C}$ virus. Hepatitis $\mathrm{C}$ virus (HCV) is a hepacivirus of Flaviviridae family (Alter et al., 1992). It is a small ( $5 \mathrm{~nm}$ in size), enveloped, positive-single stranded RNA virus (Arshad et al., 2012). Its genome is $9.6 \mathrm{~kb}$ in size, encodes a poly protein (about 3,000 amino acid) which is processed and release 3 structural ( core, E1,E2) and 7 nonstructural (P7, NS2, NS3, NS4A, NS4B, NS5A, and NS5B ) proteins (Lin et al., 1994; Reed et al.,
2000). HCV has six genotypes (1-6) and more than 100 subtypes (Bowden et al., 2006). This extensive genetic diversity is major problem for vaccine design (Friedrich et al., 2004).

$\mathrm{HCV}$ infection is a serious and one of the most important global health problems (Alter et al., 2007). It is estimated that 185 million people are infected with hepatitis $\mathrm{C}$ virus (HCV) worldwide. Prevalence is higher in some countries as 22\% in Egypt, 2 to 5 million in Europe (Rockstroh et al., 2012), 4 million in United States (Shev et al., 1995).The prevalence of hepatitis C in Pakistan is 5\% (Afridi et al., 2013) and Khyber PakhtunKhwa (KPK) is 5-9\% (Khan et al., 2004), contributing to liver cancer (Munaf et al., 2014). Each year 3 to 4 million new patient of hepatitis $\mathrm{C}$ is diagnosed (Butt, 2005; Koziel et al., 2007) and approximately 350,000 people infected with $\mathrm{HCV}$ are die every year. Most people are unaware of their HCV infection. Some persons (20 to 40\%) with acute $\mathrm{HCV}$ infection cleared spontaneously and 40 to 
$60 \%$ lead to chronic complication e.g. fibrosis, cirrhosis and hepatocellular carcinoma (HCC) (Levrero, 2006; Tang, 2009).

The analysis of HCV infection is carried out by detecting the anti-HCV antibodies using Immunochromatographic test (ICT) method (Afridi et al., 2009) and Enzyme Linked ImmunoSorbant Assay (ELISA). The Polymerase Chain Reaction (PCR) is the next main step which is used for the diagnosis of HCV infection (Gretch, 1997; Iancu, 2001; Castillo et al., 2010). The Real Time PCR is more reliable and more specific (more than 99.5\%) then the other methods (Michelin et al., 2007; Sabato et al., 2007).

Anti HCV therapy is available and quite successful. Once weekly subcutaneous injection of Pegylated interferon alpha (peg interferon alpha-2a or peg interferon alpha-2b) plus daily ribavirin (RBV) for 24 or 48 weeks, are used for the treatment of chronic hepatitis infection in most of the world (Ghany et al., 2009) and remained unchanged for the last ten years (Fried et al., 2002). The primary goalof interferon therapies are the achievement of sustained virological response (SVR), which is undetectable viral load in six months after the end of therapy (Martinot-Peignoux et al., 2010). Patient infected with genotype 2 and or 3 provides more favorable response to the treatment with peg interferon and ribavirin than those infected with genotype 1 and or 4 (Munir et al., 2010; Mangia, 2012).

Pegylated interferon is expensive, therefore in under developed and developing countries including Pakistan, most of the patient try herbal medicine e.g.laccase(extracted from oyster mushroom), proanthocyandin(extracted from blue berry leaves) and Rhodiolakirilowii, but there is no single significant report documented (Zuo et al., 2007; Ahmad et al., 2013). Due to high cost of pegylated interferon and ribavirin in Pakistan it is preferred to use Interferon alfa-2a plus ribavirin therapy. Pegylated interferon plus Ribavirin therapy is $10-15$ times more expensive than interferon plus ribavirin therapy.

This situation clearly demands for in depth knowledge about the ground situation regarding different Hepatitis $\mathrm{C}$ Virus genotypes and their response to different antiviral regimes in local population. In same connection the present study was designed to check the overall situation of Hepatitis C in District Mardan including the number of patients detected with $\mathrm{HCV}$, their treatment regime, the non-respondents to treatment, the relapsed patients, the genotype of virus in non-respondents and relapsed patients and any probable effect of age and sex of these patients on resistance to anti-viral therapy.

\section{Materials and Methods}

\section{Patients and samples}

The study was conducted from January 2011 to December 2013 in D.H.Q Hospital Mardan (Hepatitis Prevention and Control Program) and 3800 patients were included in the study. These patients had already completed 6-months treatment of Interferon alfa-2a (3MIU) plus Ribavirin. Blood samples from these patients were taken aseptically and sera from these samples were separated and subjected to HCV RNA-isolation and amplification through Real-Time PCR. Furthermore, detail history of these patients was taken through a Performa.

\section{RNA isolation Amplification}

RNA was isolated by using Magnesia ${ }^{\mathrm{TM}} 16$ Nucleic Acid Extraction System/Magnesia ${ }^{\mathrm{TM}}$ Viral Nucleic Acid Extraction Kit (Anatolia Geneworks) with Bosphore ${ }^{\mathrm{TM}}$ HCV Quantification Kit v.1.The RNA isolated was subjected to Real Time PCR for diagnosis of HCV Genome. The following procedures were adopted.

The master mix was prepared for RT-PCR $24 \mu 1$ of master mix and $16 \mu 1$ of sample RNA was transferred to PCR tubes, similarly standard, positive and negative control were made. These PCR tubes were transferred to PCR machine. The different parameters were inserted in Real Time PCR machine as per protocol. After completion of 50 cycles of Real Time PCR results were obtained by taking reading from threshold cycles (Tc). Further genotypes of all non-respondents and relapsed patients identified were determined. The Genotyping was performed as per following procedure in Genome Center for Molecular Based Diagnostic and Research, Johar Town, Lahore.

\section{Genotyping of Non-Responders and Relapsed Patients}

All HCV genotypes were identified by using HCV Genotyping Kit from AnaGen (USA). HCV RNA was isolated from $150 \mu 1$ serum of the patient and was reverse transcribed into cDNA with Molony-murine leukemia virus reverse transcriptase enzyme. The cDNA was subjected to two rounds of PCR amplification. The 1stround utilized the outer primers specific for the core region. The 2 nd round was performed with one universal inner-sense and 12 genotype-specific anti-sense primers. The PCR products were electrophoresed on a $2 \%$ agarose gel, stained with ethidiumbromide and evaluated on UV trans-illuminator. The HCV genotype for the sample was determined by identifying the genotype-specific cDNA band.

Non-Responders and Relapsed patients were again subjected to 6-months of anti-HCV treatment by replacing Interferon alfa-2a (3MIU) plus Ribavirin with PEGInterferon alfa-2a $(180 \mu \mathrm{g})$ and Ribavirin therapy. After 6-months therapy these all patients were again checked for presence of HCV-RNA through real-time PCR.

\section{Results}

Table 1. Genotypes of Non-responders and Relapsed Patients and their Status after Taking PEG-Interferon plus Ribavirin for 6 Months

\begin{tabular}{lcccc}
\hline S.NO & Genotype & Negative* $^{*}$ & Positive* $^{*}$ & Total \\
\hline 1 & $3 \mathrm{a}$ & 82 & 12 & 94 \\
2 & $3 \mathrm{~b}$ & 3 & 1 & 4 \\
3 & $2 \mathrm{a}$ & 12 & 2 & 14 \\
4 & $1 \mathrm{a}$ & 2 & 1 & 3 \\
5 & $1 \mathrm{~b}$ & 3 & 1 & 4 \\
6 & Mixed & 4 & 0 & 4 \\
7 & Un-typed & 4 & 1 & 5 \\
\hline \multicolumn{5}{r}{ *HCV RNA after PEG-Interferon Plus Ribavirin Therapy }
\end{tabular}


Hepatitis C Virus Genotypes and Resistance to Anti-Viral Treatment in Mardan, Pakistan Table 2. Age and Sex wise Distribution of Genotypes of Non-responder Patients (Male)

\begin{tabular}{|c|c|c|c|c|c|c|c|c|c|c|c|}
\hline S.NO & Age(years) & & & & noty & & & & Become Negative* & * Remain Positive* & Total \\
\hline & & $3 a$ & $3 b$ & $2 \mathrm{a}$ & $1 \mathrm{a}$ & $1 \mathrm{~b}$ & Mixe & -typed & & & \\
\hline 1 & $15-35$ & 08 & 1 & 2 & 0 & 0 & 0 & 1 & 10 & 02 & 12 \\
\hline 2 & $36-45$ & 16 & - & 2 & 1 & 1 & 1 & 1 & 20 & 02 & 22 \\
\hline 3 & $46-55$ & 08 & 1 & 1 & 1 & 2 & 1 & 2 & 09 & 07 & 16 \\
\hline 4 & $>55$ & 04 & 1 & 1 & - & - & & 0 & 04 & 03 & 06 \\
\hline$\overline{\text { Total }}$ & & 36 & 3 & 6 & 2 & 3 & 2 & 4 & 43 & 14 & 56 \\
\hline
\end{tabular}

Table 3. Age and Sex wise Distribution of Genotypes of Non-responder Patients (Female)

\begin{tabular}{|c|c|c|c|c|c|c|c|c|c|c|c|}
\hline \multirow[t]{2}{*}{ S.NO } & \multirow[t]{2}{*}{ Age(years) } & \multicolumn{7}{|c|}{ Genotype } & \multirow[t]{2}{*}{ Become Negative* } & \multirow[t]{2}{*}{ Remain Positive* } & \multirow[t]{2}{*}{ Total } \\
\hline & & $3 a$ & $3 b$ & $2 \mathrm{a}$ & $1 \mathrm{a}$ & $1 \mathrm{~b}$ & Mixed & Un-typed & & & \\
\hline 1 & $15-35$ & 12 & 1 & 3 & 0 & 1 & 0 & 0 & 16 & 1 & 17 \\
\hline 2 & $36-45$ & 31 & 0 & 2 & 0 & 1 & 0 & 0 & 34 & 0 & 34 \\
\hline 3 & $46-55$ & 9 & 0 & 3 & 0 & 0 & 1 & 1 & 11 & 3 & 11 \\
\hline 4 & $>55$ & 02 & 0 & 0 & 0 & 0 & 0 & 0 & 02 & 0 & 02 \\
\hline Total & & 54 & 1 & 8 & 0 & 2 & 1 & 1 & 63 & 04 & 67 \\
\hline
\end{tabular}

In this study 3800 patients that have already taken Interferon alfa-2a (3MIU) plus Ribavirin treatment for 6-months were selected and subjected to Real Time PCR to check the viral response to anti-viral therapy. Among these 3677 (97\%) patients showed no detectable HCV RNA on PCR while 123 (3\%) patients (Non-respondents) were still remained positive for HCV RNA.

The Genotype of 128 samples (including 123 samples of non-responder patientsand five from relapsed patients) were determined and subjected to PEG-Interferon alfa2a $(180 \mu \mathrm{g})$ and Ribavirin therapy for next 6 months. It resulted into elimination of HCV RNA from 110 patients but yet 18 patients had clues of HCV RNA. The Genotype of these all samples analyzed showed that most of them belong to 3a genotype while the samples resistant to antiviral treatment were gone to other genotypes. Furthermore, viral RNA from 06 patients couldn't be recognized and remained un-typed while 04 patients showed mixed infection (Table 1).

The genotypes and age wise distribution of Male non-responders and Female non-responders patients are mentioned in Table 2 and 3 respectively. HCV was found more resistant to antiviral therapy in female as compared to male. Age group 36-45 in both female and male was found most effected with infection (Table 2 and 3 ). Relapsed patients responded well to PEG-Interferon alfa$2 \mathrm{a}(180 \mu \mathrm{g})$ and Ribavirin treatment and four out of five patients sera showed no detectable virus while one female patient having 3a genotype didn't respond to treatment.

\section{Discussion}

In this study the End of Treatment Response (ETR), (Defined as the absence of HCV RNA at the end of six months Interferon (INF) therapy) of standard INF-alfa$2 \mathrm{a}(3 \mathrm{MIU})$ and Ribavirin combination therapy was $97 \%$ while $0.3 \%$ did not respond to therapy. Resistance to INF alfa-2a (3MIU) plus Ribavirin therapy is common and similar results demonstrated by Ahmad et al. (2013) and Bashir et al. (2012) that $19 \%$ and $25.28 \%$ of patients in their studies respectively, didn't respond to the INF alfa- 2a (3MIU) plus Ribavirin therapy. In addition to routine resistance of different viral genotypes and immunodeficiencies of the host few other observations were made that may add in failure to respond positively to antiviral therapy. It has been noted that some patients take their medicines to their homes rather injecting on spot in front of health officer of the Hepatitis Control Program just to avoid schedule revisits to health center. They keep these medicines and injectable in their home as per their will and not following the instructions of the manufacturer. They keep these medicines and injectable in refrigerator and freezers with the knowledge that daily electricity failure in Pakistan extends sometimes up to 8-10 hours and in some cases the patients stored these medicines in water pots. This mismanagement and not following the cold chain can further hinder to achieve a good ETR.

It is observed that most of the hepatitis $\mathrm{C}$ viruses belong to $3 \mathrm{a}$ and $2 \mathrm{a}$ genotype and highest Sustained Virological Response (SVR), after using PEG-Interferon alfa-2a $(180 \mu \mathrm{g})$ Plus Ribavirin, has been observed $(87 \%$ and $85 \%$, respectively) in these two groups. These results are in compliance with Jerzy et al. (2013) who demonstrated that HCV genotype 2 and 3 depicted 70$90 \%$ SVR. Similarly Saira et al. (2010) reported $80 \%$ SVR for HCV genotype 2 and 3. The most prevalent genotype in District Mardan is 3a but it responded well to anti-viral therapy. Other genotypes (1a and $1 \mathrm{~b}$ ) were also found but their presence and circulation was rare but it was evident that resistance to anti-viral therapy was seen more in $1 \mathrm{a}$ and $1 \mathrm{~b}$ genotypes ( $33 \%$ and $25 \%$, respectively) as compared to other genotypes. Similar observation were noted by Shepherd et al. (2004) that best sustained virological response (SVR) was seen for genotype 3 and 2 as compared to genotype 1. Micheal et al. (2001) reported $42 \%$ SVR for genotype 1 and $80 \%$ SVR for genotype 2 and 3 in response to PEG-interferon alfa-2a (180 $\mu \mathrm{g})$ plus ribavirin therapy

The dominant group of HCV patients in this study that didn't respond to interferon alfa-2a (3MIU) plus ribavirin was female (55\%) as compared to male $(45 \%)$ but resistance ratio after PEG-interferon alfa-2a plus 


\section{Noreen Akhtar et al}

ribavirin was higher in male as compared to female patients. Resistance to anti-viral therapy was $25 \%$ and $6 \%$ observed in male and female, respectively. Female patients responded well as compared to male patients. Resistance to antiviral therapy (interferon plus ribavirin) was significantly noted in age group of 36-45 in both male and female patients that became $90 \%$ and $100 \%$ SVR, respectively after therapy with PEG-interferon alfa2a $(180 \mu \mathrm{g})$ plus ribavirin. In age group 46-55 the SVR became $22 \%$ and $72 \%$ in male and female, respectively after treatment with PEG interferon alfa-2a (180 $\mu \mathrm{g})$ plus ribavirin. It clearly indicates a decrease in response to PEG-interferon alfa-2a $(180 \mu \mathrm{g})$ plus ribavirin therapy with increasing age especially in case of male.

\section{Acknowledgements}

The authors are highly thankful to the District Head Quarter Mardan, KPK, for providing facility for carrying out this research work.

\section{References}

Afridi S, Naeem M, Hussain A, et al (2009). Prevalence of hepatitis $\mathrm{C}$ virus (HCV) genotypes in Balochistan. Mol Biol Rep, 36, 1511-4.

Afridi SQ, Zahid MN, Shabbir MZ, et al (2013). Prevalence of HCV genotypes in district Mardan. Virol J, 10, 10-90.

Ahmad B, Ali S, Ali I, Azam S, Bashir S (2012). Response rates of standard interferon therapy in chronic HCV patients of Khyber Pakhtunkhwa (KPK). Virol J, 9,18.

Ahmad B, Ali S, Ali I et al (2013). Conventional Interferon Therapy Response among Chronic HCV Patients in Khyber Pakhtunkhwa. J Infect Dis Ther, $1,104$.

Alter MJ, Margolis HS, Krawczynski K, et al (1992). The natural history of community-acquired hepatitis $\mathrm{C}$ in the United States. N Engl J Med, 327, 1899-905.

Alter MJ (2007). Epidemiology of hepatitis C virus infection. World J Gastroenterol, 13, 2436-41.

Arshad A, Arshad M, Pervaiz R, et al (2012). Prevalance of Active Hepatitis-C infection in the general population of district Mardan, Khyber Pakhtunkhwa. Pakistan J Public Health Biological Sci, 1, 3-8.

Butt AA (2005). Hepatitis C virus infection: the new global epidemic. Expert Rev Anti Infect Ther, 3, 241-9.

Bowden DS, Berzsenyi MD (2006). Chronic hepatitis C virus infection: genotyping and its clinical role. Future Microbiol, 1, 103-12.

Castillo I, Bartolome J, Quiroga JA, Barril G, Carreno V (2010). Diagnosis of occult hepatitis $\mathrm{C}$ without the need for a liver biops. J Med Virol, 82, 1554-9.

Frank C, Mohamed MK, Strickland GT, et al (2000).The role of parenteral antischistosomal therapy in the spread of hepatitis C virus in Egypt. Lancet, 35, 5887-91.

Fried MW, Shiffman ML, Reddy KR, et al (2002). Peginterferon alfa-2a plus ribavirin for the chronic hepatitis $\mathrm{C}$ virus infection. $N$ Engl J Med, 347, 975-82.

Friedrich TC, Dodds EJ, Yant LJ, et al (2004). Reversion of CTL escape-variant immunodeficiency viruses in vivo. Nat Med, 10, 275-81.

Ghany MG, Strader DB, Thomas DL, Seeff LB (2009). American association for the study of liver diseases. diagnosis, management, and treatment of hepatitis $\mathrm{C}$ : an update. Hepatology, 49, 1335-74.

Gretch DR (1997). Diagnostic tests for hepatitis C. Hepatology,
299, 435-75.

Iancu LS (2001). Diagnostic strategies in hepatitis C virus infection. Rev Med Chir Soc Med Nat Iasi, 105, 37-42.

Kanda T, Yokosuka O, Omata M (2013). Hepatitis C Virus and Hepatocellular Carcinoma. Biology, 2, 304-16.

Khan MSA, Khalid M, Ayub N, Javed M (2004). Seroprevalence and risk factors of Hepatitis $\mathrm{C}$ virus (HCV) in Mardan, N.W.F.P. Rawal Med J, 29, 57-60.

Koziel M, Peters M (2007). Viral hepatitis in HIV infection. $N$ Engl J Med, 356, 1445-54.

Levrero M (2006). Viral hepatitis and liver cancer: the case of hepatitis C. Oncogene, 25, 3834-47.

Lin C, Lindenbach BD, Pragai BM, McCourt DW, Rice CM (1994). Processingin the hepatitis C virus E2-NS2 region: identification of $\mathrm{p} 7$ and two distinct E2-specific products with different $\mathrm{C}$ termini. $J$ Virol, 68, 5063-73.

Mangia A, Mottola L (2012). What's new in HCV genotype 2 treatment? Liver Int, 1, 135-40.

Manns MP, McHutchison JG, Gordon SC, et al (2001). Peginterferon alfa- $2 b$ plus ribavirin compared with interferon alfa- $2 b$ plus ribavirin for initial treatment of chronic hepatitis C: a randomised trial. Lancet, 358, 958-65.

Martinot-Peignoux M, Stern C, Maylin S, et al (2010). Twelve weeks posttreatment follow-up is as relevant as 24 weeks to determine the sustained virologic response in patients with hepatitis $\mathrm{C}$ virus receiving pegylated interferon and ribavirin. Hepatology, 51, 1122-6.

Michelin BD, Muller Z, Stezl E, et al (2007). Evaluation of the abbott real time HCV assayfor quantificative detection of hepatitis C virus RNA. J Clin Virol, 38, 96-100.

Munaf A, Memon MS, Kumar P, Ahmed S, Kumar MB (2014). Comparison of viral hepatitis-associated hepatocellular carcinoma due to HBV and HCV - cohort from liver clinics in Pakistan. Asian Pac J Cancer Prev, 15, 7563-7.

Munir S, Saleem S, Idrees M, et al (2010). Hepatitis C treatment: current and future perspectives. Virol J, 7, 296.

Reed KE, Rice CM (2000). Overview of hepatitis C virus genome structure, polyprotein processing, and protein properties. Curr. Top. Microbiol Immunol, 242, 55-84.

Rockstroh J, Grint D, Boesecke C, et al (2012). Increases in acute hepatitis $\mathrm{C}(\mathrm{HCV})$ incidence across Europe: which regions and patient groups are affected? J Int AIDS Soc, 15, 18116.

Sabato MF, Shiffman ML, Langley MR, et al (2007). Comparison of performance characteristics of three real time reverse transcription-PCR test systems for detection and quantification of hepatitis C virus. J Clin Microbiol, 45, 2529-36.

Shepherd J, Brodin H, Cave C, et al (2004). Pegylated interferon alpha- $2 \mathrm{a}$ and $-2 \mathrm{~b}$ in combination with ribavirin in the treatment of chronic hepatitis $\mathrm{C}:$ a systematic review and economic evaluation. Health Technol Assess, 8.

Shev S, Hermodsson S, Lindholm A, et al (1995). Risk factor exposure among hepatitis $C$ virus RNA positive Swedish blood donors the role of parenteral and sexual transmission. Scand J Infect Dis, 27, 99-104.

Tang H, Grise H (2009). Cellular and molecular biology of HCV infection and hepatitis. Clin Sci, 117, 49-65.

Zuo G, Li Z, Chen L, Xu X (2007). Activity of compounds from Chinese herbal medicine Rhodiolakirilowii (Regel) Maxim against HCV NS3 serine protease. Antiviral Res, 1, 86-92. 